\title{
Introducing Functional Composite Materials
}

Tony McNally

The science and technology of composite materials has never been more important a research topic. The demands and requirements of composite materials to meet the many societal, environmental and engineering challenges for the twenty-first century and beyond are significant. Functional composite materials will play a major and wide-ranging role in addressing these challenges, whether it is solutions to address the negative aspects of climate change, for light-weighting and components for the electrification of all forms of transport, for the generation and storage of energy to sustainable composite materials for applications in construction, food packaging and space exploration.

Materials discovery continues unabated and the growth and application of new materials provides a cornucopia of starting materials such that the number of composite materials possible having a range of functionalities is limitless. Recognizing the importance and potential of functionality for the development of the next generation composite materials, the editor with Springer engaged with the leading researchers in the field, many now members of the editorial board. Without exception, all realized there was an absence in the field for a journal where it was mandatory the functionality of the composite material be, described in the manuscript. Examples include, but are not limited to, electrical and thermal conductivity/insulation; thermoelectric; magnetic; optical; shape memory; ferroelectric; energy storage; phase change and antimicrobial.

Functional Composite Materials is an interdisciplinary journal focusing on fundamental and applied aspects of composite materials spanning chemistry, physics, biology, engineering, manufacturing, modelling, theory and materials, interpreted in the broadest sense. The key requirement for publication is that the concept of functionality must be, clearly demonstrated. Functional Composite Materials will publish review articles,

Correspondence: T.McNally@warwick.ac.uk

International Institute for Nanocomposites Manufacturing (IINM), WMG, University of Warwick, Coventry CV4 7AL, UK communications, original research articles and thematic collections. As Functional Composite Materials is a fully open access journal, authors will benefit from their papers receiving unrestricted access around the world, as well as retaining copyright under a Creative Commons licence.

\section{Author's contributions \\ The author wrote and approved the final manuscript. \\ Competing interests \\ The author declares that he has no competing interests.}

Received: 31 March 2020 Accepted: 2 April 2020

Published online: 18 May 2020

\section{Publisher's Note}

Springer Nature remains neutral with regard to jurisdictional claims in published maps and institutional affiliations.

\section{Submit your manuscript to a SpringerOpen ${ }^{\odot}$ journal and benefit from:}

- Convenient online submission

- Rigorous peer review

- Open access: articles freely available online

- High visibility within the field

- Retaining the copyright to your article

Submit your next manuscript at $\boldsymbol{s p r i n g e r o p e n . c o m ~}$
Springer Open
(๑) The Author(s). 2020 Open Access This article is licensed under a Creative Commons Attribution 4.0 International License, which permits use, sharing, adaptation, distribution and reproduction in any medium or format, as long as you give appropriate credit to the original author(s) and the source, provide a link to the Creative Commons licence, and indicate if changes were made. The images or other third party material in this article are included in the article's Creative Commons licence, unless indicated otherwise in a credit line to the material. If material is not included in the article's Creative Commons licence and your intended use is not permitted by statutory regulation or exceeds the permitted use, you will need to obtain permission directly from the copyright holder. To view a copy of this licence, visit http://creativecommons.org/licenses/by/4.0/. 